\title{
Evaluation of antibacterial, antifungal and modulatory activity of methanol and ethanol extracts of Padina sanctae-crucis
}

Lavouisier F.B. Nogueira $^{1}$, Edson C. Morais ${ }^{1}$, Maria A.D. Brito ${ }^{1}$, Beatriz S. Santos ${ }^{1}$, Doanny L. Vale ${ }^{1}$, Bruno F.F. Lucena ${ }^{1}$, Fernando G. Figueredo ${ }^{1}$, Glaucia M.M. Guedes ${ }^{2}$, Saulo R. Tintino ${ }^{2}$, Celestina E. S. Souza ${ }^{2}$, Raquel B.S.S. Nogueira ${ }^{3}$, Edinardo F.F. Matias², Maria F.B. Morais-Braga², Emídio V.L. Cunha ${ }^{3}$, Micheline A. Lima ${ }^{3}$, Henrique D.M. Coutinho²*

1. Faculdade de Ciências Aplicadas Doutor Leão Sampaio (College), Juazeiro do Norte - CE, Brasil

2. Departamento de Química Biológica, Universidade Regional do Cariri - URCA, Crato - CE, Brasil

3. Laboratório de Tecnologia Farmacêutica, Universidade Federal da Paraíba - UFPB, João Pessoa - PB, Brasil.

\begin{abstract}
Background: Multi-resistant microorganisms such as Escherichia coli, Staphylococcus aureus, Pseudomonas aeruginosa, Candida tropicalis e Candida krusei are the main causes of microbial infections. Padina sanctae-crucis is a seaweed often used to check the contamination of ecosystems by materials such as heavy metals, but studies of the antimicrobial activity of the same seaweed were not found.

Methods: The tests for the minimum inhibitory concentration and modulation of microbial resistance, with the use of ethanolic and methanolic extracts of Padina Sanctae-cruces combined with drugs of the class of aminoglycosides and antifungal were used to evaluate the activity against the cited microorganisms.

Results: Was observed a modulation of antibiotic activity between the natural products and the E. coli and S. aureus strains, indicating a synergism and antagonism respectively.

Conclusions: The results showed a moderate modulatory effect against some microorganisms studied.

Keywords: multi-resistant microorganisms, modulation, Padina Sanctae-crucis, antimicrobial activity.

African Health Sciences 2014; 14(2):372-376
\end{abstract}

DOI: http://dx.doi.org/10.4314/ahs.v14i2.12

\section{Introduction}

The World Health Organization (WHO) ${ }^{1}$ defines medicinal plants as any plant which in one or more of its organs contains active ingredients which can be used for therapeutic purposes or contain compounds that can be used for the synthesis of useful drugs ${ }^{1}$.

The population of the poorest countries uses medicinal plants by symbolic tradition associated with low cost of this treatment, but in most developed countries there is an increased use of herbal medicines influenced by fad consumption of natural products ${ }^{2,3}$.

Medicinal plants and their products have been used as self-medication based on traditional knowledge ${ }^{4-6}$. The ethnopharmacological studies have cataloged lately a large number of plants used by the samepeople who got their medica 1 activities confirmed ${ }^{4-6}$.

\section{*Corresponding author:}

Henrique D.M. Coutinho

Universidade Regional do Cariri

Departamento de Química Biológica,

Av. Cel. Antônio Luiz, 1161

CEP:63105-000. Crato, CE. Brasil.

Phone: +558831021212. Fax: +558831021291.

E-Mail: hdmcoutinho@gmail.com
The growing interest in medicinal plant research in recent decades is due to an increasing apparition of adverse effects of conventional drugs and the increase of microbial resistance to antibiotics, the researchers are looking more carefully the natural products that could provide effective treatment for diseases and infections and a low toxicity to the patient ${ }^{7,8}$.

Two main factors are crucial to microbial resistance: the emerging and re-emerging diseases and the resistance to antibiotics ${ }^{9}$. The resistance to antibiotics is a process of natural selection, selecting the most resistant microorganisms of a group or selecting those that have the ability to adapt, either by mutation or obtaining resistance factors transmitted by another microorganism ${ }^{9}$. Several chemical compounds, synthetic or from natural sources, have direct activity against many species of bacteria, enhancing the activity of a specific antibiotic, reversing the natural resistance of bacteria to specific antibiotics, causing the elimination of plasmids, and inhibiting the active efflux of antibiotics through the plasma membrane ${ }^{10,11}$. The potentiation of antibiotic activity or the reversal of antibiotic resistance allows the classification of these compounds as modifiers of antibiotic activity ${ }^{10,11}$.

This search for more effective active ingredients and less dangerous to humans and for a greater effectiveness against some microorganisms 
puts the herbal medicines studies in a significant level in the scientific research, opening up opportunities for ethnopharmacological studies, phytochemical e microbiological among any other areas ${ }^{7}$.

Padina sanctae crucis is part of the Eukaryotic group, being found as integrant of kingdom Chromista, in which is classified part of the phylum Ochropyita and subphylum Phaeista, is also classified as a integrant of class Phaeophyceae and is within the order Dictyotales, Dictyotaceae family belonging to the genus Padina ${ }^{12}$.

The specific taxonomic study of gender Padina is usually very difficult due to the the lack of uniformity that is found in the literature about the characteristics that should be taken into consideration for species differentiation. In Brazil, by the year 2000, there were no taxonomic studies that explain about only this genus ${ }^{13}$.

The research objective was evaluate the action of spectrum and the minimum inhibitory concentration (MIC) of extracts obtained from leaves of Padina sanctae crucis against pathogenic strains of fungi and bacteria. Besides that, determine the effectiveness of the extracts in the modulation of fungal and bacterial resistance to aminoglycosides and antifungal.

\section{Methods \\ Microbial strains}

The bacteria used in test of Minimun Inhibitory Concentration (MIC) were the standard strains of Escherichia coli ATCC 10536, Staphylococcus aureus ATCC 25923, Pseudomonas aeruginosa ATCC 15442. To evaluate the modulatory activity of the natural products were used the follow multiresistants bacterial strains isolated from clinical environments: Pseudomonas aeruginosa 03, Escherichia coli 27 and Staphylococcus aureus 358.

The fungal strains utilized were: Candida tropicalis 40042:Candida krusei 2538. All the strains were maintained in slants with Heart Infusion Agar (HIA; Difco Ltda) and before the tests the cells were cultured by 24 hours at $37^{\circ} \mathrm{C}$ in brain heart infusion. (BHI,Difco Laboratories Ltda).

\section{Drugs and Natural Products}

The methanol and ethanol extracts were obtained from Dr. Emídio V. L. da Cunha, Laboratory of Pharmaceutical Technology - UFPB, Brazil. The drugs used in the tests were the aminoglycosides: Amikacin, Gentamicin and Neomycin (Sigma Co., St. Louis, USA). All the drugs were dilluted using sterile water. The antifungal drugs used in the tests were: Anphotericin B; Nystatin; Mebendazole and Benzoilmetronidazol, the antifungal drug solutions were prepared according to the manufacturer's instructions.

\section{Phytochemical prospecting}

The qualitative phytochemical tests to detect the presence of phytocompounds were performed according to the method described by Matos ${ }^{14}$. The tests were based on the visual observation of a change in color or formation of precipitate after the addition of specific reagents.

\section{Minimal Inhibitory Concentration}

The method used was microdilution in broth. The metanolic and etanolic solution of Padina sanctaecruces was solved using DMSO and diluted to $1024 \mu \mathrm{g} /$ $\mathrm{mL}$ using sterile distilled water. The bacterial inoculum was diluted using BHI $10 \%$ to a final concentration of $10^{5} \mathrm{UFC} / \mathrm{mL} .100 \mu \mathrm{L}$ of the inoculums were distributed on each well of a microtiter plate with 96 wells and then submitted to a twofold serial dilution using $100 \mu \mathrm{L}$ of the extract, ranging the concentrations between 512 to $8 \mu \mathrm{g} / \mathrm{mL}$. The plates were incubated for 24 hours at $35^{\circ} \mathrm{C}^{15}$. The determination of bacterial MIC was made using the indicator resazurin, while the MIC of fungi were determined by the turbidity. The MIC was defined as the lowest concentration where no growth can be observed, according CLSI ${ }^{16}$.

\section{Test of Drugs Modulation}

To verified if the natural product would alter the action of antimicrobial drugs against the strain tested, was used the method proposed by Coutinho et al. ${ }^{10}$. The Methanolic and ethanolic extract of Padina sanctae-crucis was tested in sub-inhibitory concentration $(\mathrm{MIC} / 8=$ $128 \mu \mathrm{g} / \mathrm{mL}$ ). Were distributed $100 \mu \mathrm{L}$ of a solution containing BHI, the microbial inoculums and extract in each well. After this, $100 \mu \mathrm{L}$ of the antimicrobial drug was mixed with the first well, following the twofold dilution, ranging the concentrations of aminoglycosides and antifungals between 2500 to $2.44 \mu \mathrm{g} / \mathrm{mL}$ and 512 to $2 \mu \mathrm{g} / \mathrm{mL}$ respectively.

\section{Results and discussion}

The phytochemical prospection shows the presence of phytocompounds, such as phenols, tannins, flavonoids and terpenes. The phenols and tannins have a very reported antimicrobial activity associated with the hydrolysis of an ester bond with gallic acid, thereby serving as a mechanism of natural defense against microbial infections ${ }^{17}$.

Flavonoids are synthesized by plants in response to microbial infection and are effective against a broad 
range of microorganisms ${ }^{18}$. The activity is probably due to their capacity to form complexes with extracellular soluble proteins, linked with the bacterial cell wall and with the cell membrane. Terpenes occur in the form of diterpenes, triterpenes, tetraterpenes as well as hemiterpenes and sesquiterpenes, all with several reports about the antibacterial activity ${ }^{19}$.

In the last years, various studies have been conducted in different countries, demonstrating the efficacy of biological activities of medicinal plants ${ }^{20}$. There are few reports about the bioactivities of seaweeds from the species Padina sanctae crucis, being this work the first report about the antimicrobial and modulatoryantibiotic activities of Padina sanctae crucis $^{21}$.

Were found for MIC tests against bacterial strains of: (Escherichia coli ATCC10536; Staphylococcus aureus ATCC25923 and Pseudomonas aeruginosa
ATCC15442), and against the fungal strains of: (Candida tropicalis ATCC40042 and Candida kruzei ATCC2538), results that were shown at a concentration of $\geq 1024$. Those tests that were seen above or equal to 1024 do not represent a clinically significative result, but this characteristic can be changed in the modulation tests.

Several natural products such as extracts and essential oils from plants had been shown to modify antibiotic activity, using the contact direct method, as Turnera ulmifolia, Momordica charantia, Mentha arvensis, Cordia verbenaceae, and others ${ }^{10,22}$.

The results in Table 1 and Table 2 were found for the tests of modulation of microbial resistance against multiresistant bacterial strains of: Escherichia coli 27 (EC27), Staphylococcus aureus 358 (SA358), Pseudomonas aeruginosa 22 (PA22) and two fungal strains: Candida tropicalis ATCC40042 and C. krusei ATCC2538.

Table 1. Modulation of antibiotic activity of EEPSC and MEPSC combined with aminoglycosides (g. $\left.\mathrm{mL}^{-1}\right)$.

\begin{tabular}{lccc}
\hline \multicolumn{1}{c}{ EC27 } & EEPSC & MEPSC & Antibiotic alone \\
\hline Amikacin & 78,1 & 9,8 & 78,1 \\
Neomycin & 9,8 & 19,5 & 78,1 \\
Gentamicin & 2,4 & 2,4 & 2,4 \\
\hline SA358 & EEPSC & MEPSC & Antibiotic alone \\
\hline Amikacin & 19,5 & 19,5 & 19,5 \\
Neomycin & 39,1 & 39,1 & 4,8 \\
Gentamicin & 2,4 & 2,4 & 2,4 \\
\hline \multicolumn{1}{c}{ PA22 } & EEPSC & MEPSC & Antibiotic alone \\
\hline Amikacin & 312,5 & 312,5 & 312,5 \\
Neomycin & 312,5 & 312,5 & 312,5 \\
Gentamicin & 19,5 & 19,5 & 19,5 \\
\hline
\end{tabular}

The results were relevant in modulating the resistance of the strain of EC27 when EEPSC was associated with neomycin and MEPSC when associated with amikacin. In both cases was observed a reduction of 3 points of MIC as can be seen comparing the results with the control and the reference values.

The seaweed can produce several secondary metabolites and consequently express many biological activities. They are capable to synthesize halogens metabolites that can belong practically to all chemical classes from short-chain hydrocarbon, simple ketones, phenols and acetogenins up sophisticated terpenes ${ }^{23}$.

The seaweed are similar to land plants in relation to the production of substances generically called secondary metabolites, such as terpenes, compounds aromatics, acetogenins, amino acid derivatives and especially polyphenols (halides and sulfates). These compounds give the seaweed stronger antioxidant activity. And for that reason may perhaps be associated with a possible antimicrobial activity ${ }^{24,25}$.

The inhibition mechanisms of the growth of microorganisms are due in part to the hydrophobic nature of some components. As a result, they can interact with the cell membrane, affecting the respiratory chain and the production of energy or even make the cell more permeable to antibiotics ${ }^{22}$. These mechanisms of action can be obtained by the combination of antibiotic with extract at a sub-inhibitory concentration applied directly to the culture medium ${ }^{20,25}$.

This strategy is called "potentiation of activity multi-effect targeting" and refers to the utilization of plants and drugs in an approach using combinations, 
affecting various targets, where the different therapeutic components collaborate in a potential mechanism of action manner. This approach is not only for combinations of extracts; combinations between natural products or extracts and synthetic products or antibiotics are also possible ${ }^{25}$.

Table 2. Modulation of antifungal activity of EEPSC and MEPSC combined with antifungals (g.mL $\left.{ }^{-1}\right)$

\begin{tabular}{lccc}
\hline \multicolumn{1}{c}{ CT-ATCC40042 } & EEPSC & MEPSC & Antifungal alone \\
\hline Mebendazole & $\geq 1024$ & $\geq 1024$ & $\geq 1024$ \\
Anphotericin B & $\geq 1024$ & $\geq 1024$ & $\geq 1024$ \\
Nystatin & $\geq 1024$ & $\geq 1024$ & $\geq 1024$ \\
Benzoilmetronidazol & $\geq 1024$ & $\geq 1024$ & $\geq 1024$ \\
\hline \multicolumn{1}{c}{ CK-ATCC2538 } & EEPSC & MEPSC & Antifungal alone \\
\hline Mebendazole & $\geq 1024$ & $\geq 1024$ & $\geq 1024$ \\
Anphotericin B & $\geq 1024$ & $\geq 1024$ & $\geq 1024$ \\
Nystatin & $\geq 1024$ & $\geq 1024$ & $\geq 1024$ \\
Benzoilmetronidazol & $\geq 1024$ & $\geq 1024$ & $\geq 1024$ \\
\hline
\end{tabular}

It was possible observe that the strain of SA358 there was a case of antagonism of the product with neomycin, because there was an increase in bacterial resistance quantified in 3 points of $\mathrm{MIC}$ as can be seen comparing the results with the control and with the reference values. In the modulation of the fungi it was observed that the both natural products had no effect even when combined with the antifungal drugs because the results presented all equal to those found in control, thereby making the result irrelevant. In the literature there was not found any research that cite the antifungal activity of the Padina sanctae crucis.

\section{References:}

1. WHO - World Health Organization. Regulatory situation of herbal medicines. A Worldwide Review. WHO, Geneva. 1998.

2. Veiga Jr VF, Maciel MAM, Pinto AC. Plantas medicinais: cura segura? Quimica Nova 2005; 28: 51928.

3. Cascaes EA, Falchetti ML, Galato D. Perfil da automedicação em idosos participantes de grupos da terceira idade de uma cidade do sul do Brasil. Arquivos Catarinenses de Medicina 2008; 37: 63-9

4. Da Silveira PF, Bandeira MAM, Arrais PSD. 2008. Farmacovigilância e reações adversas às plantas medicinais e fitoterápicos: uma realidade. Revista Brasileira de Farmacognosia 2008; 18: 618-26.

5. Elisabetsky E. The status of ethnopharmacology in Brazil. Journal of Ethnopharmacology 1993; 38: 137.

6. Campesato VR. 2005. Uso de plantas medicinais durante a gravidez e risco para malformaçoes congênitas. UFRGS, Porto Alegre.
7. Recio MC, Rios JL. A review of some antimicrobial compounds isolated from medicnal plants reported in the lieterature 1978-1988. Phytotherapy Research 1989; 3: 117-25.

8. Silveira GP. Estratégias utilizadas no combate a resistência bacteriana. Quimica Nova 2006; 29: 844-55.

9. Kohanski MA, Depristo MA, Collins JJ. Sub-lethal antibiotic treatment leads to multidrug resistance via radical-induced mutagenesis. Molecular Cell 2010; 37: 311-20.

10. Coutinho HDM, Costa JG, Lima EO, Falcão-Silva VS, Siqueira-Jr JP. Herbal therapy associated with antibiotic therapy: Potentiation of the antibiotic activity against methicillin - resistant Staphylococcus aureus by Turnera ulmifolia L. BMC Complementary and Alternative Medicine 2009; 9: 13.

11. Coutinho HDM, Costa JG, Lima EO, Falcão-Silva VS, Siqueira-Jr JP. Effect of Momordica charantia L. in the resistance to aminoglycosides in methicilin-resistant Staphylococcus aureus. Comparative Immunology Microbiology and Infectious Disease 2010; 33: 467-71.

12. Guiry MD. AlgaeBase. World-wide electronic publication, National University of Ireland, Galway. Source: http://www.algaebase.org; Searched at 04/ December/2011.2011

13. Nunes JMC, De Paula EJ. Estudos taxonómicos do género Padina adanson (dictyotaceae - phaeophyta) no litoral do estado da Bahia, Brasil. Acta Botanica Brasilica 2000; 25: 21-43.

14. Matos FJA. Introdução à Fitoquímica

Experimental. $2^{a}$ Ed. Edições UFC, Fortaleza. 1997. 15. Javadpour MM, Juban MM, Lo WC, Bishop SM, Alberty JB, Cowell SM, Becker JM, McLaughlin ML. De 
Novo Antimicrobial Peptides with Low Mammalian Cell Toxicity. Journal of Medicinal Chemistry 1996; 39: $3107-$ 3113.

16. CLSI - Clinical and Laboratory Standards Institute. Reference method for broth dilution antifungal susceptibility testing of yeasts. Approved Standard Second Edition (M27-A2). NIH, Atlanta. 2003.

17. Ho KY, Tsai CC, Huang JS, Chen CP, Lin TC, Lin CC. Antimicrobial activity of tannin components from Vaccinium vitisidaea L. Journal of Pharmacy and Pharmacology 2001; 53: 187-191.

18. Dixon RA, Dey PM, Lamb CJ. Phytoalexins: enzymology and molecular biology. Advances in Ensymology and Related Areas of Molecular Biology 1983; 55: 1-69.

19. Ahamd AA, Mahmoud AA, Williams HJ, Scott AI, Reibebspies JH, Mabry TJ. New sesquiterpene a-methylene lactones from the Egyptian plants Jasonia candicans. Journal of Natural Products 1993; 56: 1276-80.

20. Coutinho HDM, Costa JGM, Siqueira-JR JP, Lima EO. In vitro anti-staphylococcal activity of Hyptis martiusii Benth against methicillin-resistant Staphylococcus aureus-
MRSA strains. Brazilian Journal of Pharmacognosy 2008; 18: 670-5.

21. Amado-Filho GM, Salgado LT, Rebelo MF, Rezende CE, Karez CS, Pfeiffer WC. Heavy metals in benthic organisms from Todos os Santos Bay, Brazil. Brazilian Journal of Biology 2008; 68: 95-100.

22. Matias EEF, Santos KKA, Almeida TS, Costa JGM, Coutinho HDM. Enhancement of Antibiotic Activity by Cordia verbenacea DC. Latin American Journal of Pharmacy 2010; 29: 1049-52.

23. Carvalho LR, Roque NF. Fenóis halogenados e/ou sulfatados de macroalgas marinhas. Quimica Nova 2000; 23: 757-764.

24. Nagai T, Yukimoto T. Preparation and functional properties of beverages made from sea algae. Food Chemistry 2003; 81: 327-332.

25. Coutinho HDM, Costa JG, Lima EO, Falcão-Silva VS, Siqueira-Jr JP. Enhancement of the antibiotic activity against a multiresistant Escherichia coli by Mentha arvensis L. and chlorpromazine. Chemotherapy 2008; 54: 328-30. 